\title{
Private Banking in Russia: Challenges and Prospects For the Future
}

\author{
Elizaveta S. Sokolova ${ }^{1}$, Natalya V. Toropova ${ }^{1}$, Elnur T. Mekhdiev ${ }^{1}$, Alexander S. Fedyunin ${ }^{2}$ \\ ${ }^{1}$ Center for Analysis, Risk Management and Internal Control in Digital Space \\ ${ }^{2}$ Department of World Economy and World Finance \\ Financial University under the Government of the Russian Federation
}

Moscow, Russia

\begin{abstract}
This article is devoted to the peculiarities of optimizing the relationship of high net worth individuals (HNWI) with Russian and foreign banks offering services in the field of private banking. The authors consider organization issues of HNWI banking in different banks, especially the relationship between bank personal managers and clients, requirements to banks and personal managers providing private banking services, recommendations to HNWI for choosing banks and managing investments are also considered.
\end{abstract}

Keywords—private banking; banking in Russia; HNWI clients; personal manager; HNWI banking services; bank client

\section{INTRODUCTION}

The need of high net worth individuals (HNWI) for a competent personal manager is due to the fact that owning large amounts of money does not imply the ability to manage it Even experienced people, skilled in the field of business and finance, can show surprising lightheadedness and make unreasonable and ridiculous decisions about investing all their money in the financial pyramid or entrusting it to an obvious scammer promising unrealistic profits. Therefore, it is important for HNWI not only to be able to consult a competent specialist, but also to have a number of reliable partners capable of keeping them from hasty actions.

If an ideal situation is considered, the HNWI client must independently acquire all knowledge of money management and use the bank only as a tool for the implementation of his plans. But this model is only suitable for those HNWI who have earned a fortune using other people's money, so by the time they moved to the HNWI category they already had all the necessary professional skills.

A sufficient level of qualification of fund management appears only several years after the start of such activities, therefore, capital is likely to be lost much earlier. Without a personal manager, an ordinary client cannot do anything except deposit money into a bank account, but given the likelihood of a bank failing and very moderate insurance compensation, the client will have to think about diversifying and monitoring banks.

Usually the main criterion of the HNWI reference category is the amount of client's deposit. Its minimum size can be estimated as 1 million dollars in large banks. The size of a loan as the main criterion is dubious, because there can appear some problems, in particular a big loan to a person may be connected with various tricks and money laundering transactions, when a large amount of real cash received by the borrower will be delivered to the guarantor and repaid later by him after the loan maturity date.

The most significant changes occurred not in the private banking product lines, but in the process of dealing with clientele. It became obvious to the banks that it is impossible to meet HNWI in an ordinary branch and place them in a general queue to the bank's windows. This is connected not only with prestige and some inconveniences for the client, but also with the appearance of additional unpleasant problems. For example, among HNWI there are many famous personalities, such as singers, actors, TV presenters, etc. This popularity allows ordinary people to recognize them easily in places intended for the general public, and some of them often impose communication, trying to discuss the last speech or ask for help in solving their personal problems. Such communication causes a very unpleasant feeling for a famous person and blocks for a long time the desire to visit such places, one of which may be an unsuccessful bank.

\section{DISCUSSION}

\section{A. Theoretical aspects of the study: discussion of the basic theoretical provisions on the private banking development}

There are two definitions of private banking, very different in their general meaning, and we preferred the first alternative by which private banking is banking, investment and other financial services provided by banks to individuals with high income or significant assets with high net worth individuals.

Private banking forms a more exclusive (for especially rich) wealth management subgroup. The term "private" refers to customer service provided on a more individual basis than in mass retail banking services, usually through special banking advisors. Wealth management is referred to as an investment advisory service that includes financial planning, investment portfolio management, and a range of additional financial services, banks, and other professionals in the field. Now is spreading more and more the opinion that recently more emphasis has been placed on values created through customer

The Article was prepared under the State Assignment 2019. 
needs and new changes, rather than providing emotional satisfaction [1].

This does not apply to a private bank that is not a banking institution registered as a corporation, but due to the second definition private banking is a kind of doing banking in the form of partnership or individual ownership, in contrast to the banking activities of legal entities. Private banking is the oldest form of banking service. Over the centuries, private banking houses of Europe have played an important role in European finance, while in the USA various private banking houses occupy positions that have comparable influence and prestige. Prior to the adoption of the Banking Law of 1933, most private banking houses combined providing clients with loans and discount business, receiving deposits, acceptance, foreign exchange transaction, sale of securities and distribution of stocks through underwriting. But due to this Act they were demanded to make a choice between commercial banking with deposit business and securities business. For example, the private bank of J.P. Morgan \& Co. decided to remain in the banking sector and was reestablished as a state bank called J.P. Morgan \& Co., Inc. [2].

If we consider the first approach, an important feature of private banking is the selection of clients, or "KYC (know your customer) rule". Before offering products, services and transactions, the bank must assign each client a specific category, which depends on such factors as risk, investment goal, grace period, and knowledge of the customer market. Although each bank has its own questionnaire, they are very similar. The bank classifies a client in one of the categories defined as an investor profile [3].

In large American and European banks, not only clients who do not meet the criteria of property status and sufficiency of funds placed in the bank cannot be included in the HNWI clientele, but also customers without a reputation or with a dubious reputation, when the source of the origin of their money is not clear. Since the shadow and criminal businesses are attracting huge amounts of capital, the owners of which are very interested in at least partially legalizing it, their significant inflow into the bank, even on quite legal grounds, may later lead to unpredictable consequences, ranging from liquidity problems due to sudden massive funds outflows to long and tedious litigation. Such a clientele is cut off at the initial stage of preliminary negotiations and does not even reach the top managers of the bank who do not want to spend their time on them.

\section{B. Private banking features in Russia}

Private banking in Russia has become popularly known just twenty years ago. This concept has spread in the domestic banking sector quite recently. Prior to this, work with wealthy clients was usually limited to discounts and additional services, as well as the opportunity to meet freely with the bank's management to solve any problems and referred primarily to corporate clientele.

Attempts to combine providing private banking services and the servicing of retail clients lead to an undesirable effect. One rich client wanted to withdraw his money from his bank safe box and put it in a deposit account. Since he was treated like a HNWI, he was led to a cashiers' window, bypassing a long queue. He did not count the money, and when the cashier told him a smaller amount than he expected, a scandal broke out. Most likely, as the bank employees assumed later, he used to take money from the safe box and forget about it. The client demanded to check the amount of cash on hand and search the cashier, and all he wanted was done, but there was no any money except normally required. However, the client continued to threaten the cashier and even waited several times for her at the entrance to the bank after the end of the working day.

Accumulation of experience in dealing with these clients led to understanding of need to revise not only the methodological, but also conceptual part of this activity. The need became obvious as it was possible to split one customers stream into two flows, namely retail service clients and private banking clients that required banks to change their activity in the market. There is a problem which is expressed in the fact that different credit institutions have different lower threshold, which will allow customers to enter the HNWI zone and get individual service of the highest level [4].

Range of services in the area of private banking are advertized cautiously and if the small bank turns towards private banking it has to curtail also all advertizing activity in the retail market.

Speaking about the composition of private banking services, most often it includes banking, investment and consulting services. It should be noted that the range of domestic banking products in the private banking services line is not particularly diverse. The overdraft, deposits and rent of safety-deposit boxes, various payment cards is the most common and widespread banking services for HNWI clients, but assets management and broker services are relatively weak.

It is connected, first of all, with the fact that the domestic stock market is insufficiently develop and for gaining access to the foreign stock markets it is necessary to undergo multistage procedures of preliminary checks therefore the client who wished to invest the money in little-known papers in Japan or Korea has to wait more than a half of a year before the end of documentation process. At the same time product lines of large Swiss banks constantly are replenished with new investment products as all large foreign investment companies willingly agree to be present at these lines.

At the same time, a not simple task for a HNWI client is to choose a business partner in banking. A bank must prove the ability to keep straight and reliable not only in the days of a calmness and prosperity but also in the period of serious tests too. The special carefulness it is necessary to show with a new business partner, even if it is a good long-lived and well-known large bank.

In difficult situations, even reputable Western banks specializing in private banking for a long time may behave unpredictably. This was the case, for example, on 15 January 2015, when the National Bank of Switzerland unexpectedly changed the minimum exchange rate of the Swiss franc against the euro, which was set at 1.20 in 2011 in order to counter 
deflation and recession in the economy during the worsening crisis in the euro zone.

Until then, foreign exchange speculators could profit relatively easily from the predictability of the Swiss franc by opening positions with a 200-fold leverage. The rapid depreciation of the euro to 0.80 Swiss francs resulted in millions of losses for many bank customers, with many banks simply not answering their phone calls, even though the contracts with customers clearly stated their responsibility to do so during the period of increasing turbulence in the foreign exchange market under the so-called "best execution principle".

Subsequently, banks have tried to compensate partially their customers some losses incurred in the extrajudicial settlement, as it gave them the opportunity to minimize reputational risks, however, the events have shown that each bank has a limit on the safety margin, and the customers should first of all, rely on their own prudence and caution when assets are placed under control of any institution. [5]

The analysis of typical private banking client complaints in large Russian banks shows that they most often face indifference from the bank to the client's interests, the desire to transfer banking risks to him as much as possible and, at the same time, to get as much income from the client's capital transactions as possible. There are many examples of the client being intentionally pushed to take risky actions that are currently beneficial for the bank, but which have resulted in serious losses for the client, such as, for example, insistent recommendations to invest in the bank's own shares at the time of their placement. After the price of these shares in the market fell sharply and the client's assets were quickly depreciated, all of his claims to the bank's managers were answered with the statement that the risk was inevitable, and the market was unpredictable, but later everything would be just like it was before, the bank's shares would be again more expensive and all his losses would be offset with extra profit.

In addition, clients also often complain that the bank offers them services that they either do not want or cannot fully use, but still have to pay for them. In order to make it more difficult for the client to discuss them, especially if he does not have sufficient financial literacy, all these services are included in a single package. Negotiations are conducted by young, energetic employees who are able to speak convincingly and use professional terminology competently, they have an attractive appearance, they try to attract interlocutors and instill confidence in their success. Despite some frustration with the client later on, he retains his initial trust, and only after his manager begins to evade not only any comments about his dubious advice, which caused significant losses, but even the usual meetings and telephone conversations, the client leaves the bank. Such a relationship and the losses incurred are more and more common reason for litigation in the private banking industry, but is not yet widespread in our country.

The level of authority of a personal manager in a bank is of great importance. If this is an ordinary employee, any decision that goes beyond his or her authority and daily duties should be agreed with the management, observing the requirements of approving his or her decision passing through the steps of the bank's hierarchy. This situation usually exists in large banks, so they are characterized by a standard set of banking products, ranked according to the status of clients, based on standard technologies. Despite their diversity, they are rather strictly regulated and their individual adjustment can take a lot of time and effort not only from a personal manager, but also from his head of the department. As an example, we can cite the situation in one large Russian bank, which has absorbed the capital's bank with a large branch network. As a result of the reorganization, a new department was created, to which all the branches, including those that this bank had before, were subordinated. There were not many of these branches, they served big customers of the bank, and the heads of these branches were able to quickly resolve issues with the heads of departments of the parent bank in personal meetings without delay. With the advent of the new department it become inconvenient to solve these issues bypassing the head of the department because he felt uncomfortable and the situation caused his legitimate objections, but because of the large number of branches and increased flow of routine work it was necessary to put their questions in accordance with standard procedures, which greatly slowed down the process of solving them. As a result, this caused discontent among HNWI customers and many of them preferred other banks.

This situation is more common in large banks than in small ones, even though large banks with well-known brands look much more solid and reliable, and their capacity is much higher as they are more diverse and have more funds and human resources. At first glance, this is more than enough for a client to prefer a large bank, but then he often has to change his mind.

This is also due to the fact that the very concept of a large client is quite relative. Large or small can be the same client in a small bank it is large, and in a large - small. If for a small bank the loss of a large client is a rather unpleasant event with obvious negative consequences, for a large bank the same customer's loss is only an insignificant unfortunate episode. Brands of large, well-known banks still remain attractive for clients and their inflow without any difficulties covers the outflow of old ones.

In a small bank the management can invite personal managers with their own VIP-clientele and do everything necessary for providing them with the full range of services. In this case, the distance between the client and his personal manager is much smaller than between him and his bank, that is, the personal manager will leave the bank much faster for the sake of the client than the client for the sake of the bank. The client, passing from the bank to the bank with his manager, as a rule, gives the right to decide this issue to the manager and does not doubt the expediency of his choice.

Since the administrative vertical line is much shorter in a small bank, a personal manager can communicate directly with the heads of particular departments and the bank's top management. The position of personal manager is often given a special meaning in the eyes of HNWI and he or she may be called the head of a department or even the deputy chairman of the bank's management board, but it just a title for business cards. This is not only true for Russia. For example, Swiss banks have a group of officials with special powers to fulfill 
special requests of clients in the bank, who are referred to as "senior bankers".

\section{CONCLUSION}

A small bank can use some competitive advantage in the field of private banking. Though it has much less opportunities, but it shows much more attention to each particular client, as his importance for a small bank is much higher. Therefore, if necessary, the client can easily communicate not only with his personal manager, but also with the top management of the bank.

Despite many similarities and the long journey Russian banks have travelled over the past decade in the field of private banking, there are still notable differences between them and their foreign competitors. This is also evident in their clientele. If we compare domestic and foreign HNWI clients, the domestic clientele is characterized by a low level of financial literacy and lack of ability to manage their capital, which is often the reason for its loss. Below are the rules that are well known in developed countries, which should be followed by the client who belongs to the HNWI group.

Sources of income should be diverse, and it is not desirable to focus on one of them, as the overall sensitivity of investments to the risks inherent in this source of income increases dramatically. After well-designed diversified investments, revenue sources should generate regular cash flows.

Responsible use of money means that the client should remember that priority should be given to savings, but not to expenditures, i.e. not to save what is left over from the increase in consumption, but to consume what is left over from the increase in savings. Therefore, it is not consumption that should be planned in the first place, but saving.

Another important aspect in terms of customer cost management is the rule that when acquiring expensive status assets and luxury goods that require significant maintenance costs, sooner or later there will be a time when the assets will have to be sold if it is vitally important for the future.

Private banking does not provide for public advertising of banking services. If the same channels as in retail banking are used to attract clients, the same clients come to the bank, but with a desire to be served at a higher quality level.

The main problem of private banking in the Russian Federation is the fact that domestic private banking has so far been based on the principle of non-financial support rather than financial assistance. While managing the client's capital and demonstrating the result was undoubtedly important, it was equally important to demonstrate the client's status. Therefore, the product range of private banking has always been growing due to the additional services of the corresponding direction, first of all lifestyle management.

It is not advisable to keep all your assets in the same bank or in related banks exposed to cluster risks. When choosing a bank, it is necessary to pay attention not only to its reputation and performance results in recent years, but also to the capital adequacy of the first level and the availability of good recommendations from a personal manager. Russian and foreign banks have many personal managers who are ready to provide their clients their phone numbers and are ready to answer the call on any day of the week and any time of the day.

\section{REFERENCES}

[1] D. Kim and J. Yoo, "A Study on Space for Private Banking Clients by Leveraging Service Design Elements," Journal of Korea Institute of Spatial Design, vol.10, no. 3, pp. 85-92, 2015.

[2] Ch. J. Woelfel, Encyclopedia of Banking and Finance. Chicago, Illinois: Probus Publishing Company, 1992.

[3] L. Ferreira, D. Borenstein, M. B. Righi, and A. T. de Almeida Filho, "A fuzzy hybrid integrated framework for portfolio optimization in private banking," Expert Systems with Applications, vol. 92, pp. 350-362, 2018.

[4] P. G. Afanasieva and A. T. Chumakova, "Innovations in Commercial Banking Sector of Russia," Economics Business Banks, no. 3 (16), pp. 171-181, 2016. (In Russian)

[5] Ultimate Guide in Private Banking to Secure Your Wealth. 2018 Retrieved from: https://swiss-banking-lawyers.com/private-banking 